\title{
Pengembangan Perencanaan Pembelajaran Bermuatan Budaya Lokal Tepian Sungai pada Anak Usia Dini
}

\author{
Novitawati ${ }^{1}$, Chresty Anggreani ${ }^{\bowtie}$ \\ Pendidikan Guru Pendidikan Anak Usia Dini, Universitas Lambung Mangkurat $(1,2)$ \\ DOI: $\underline{10.31004 / o b s e s i . v 6 i 1.767}$
}

\begin{abstract}
Abstrak
Penelitian pengembangan ini bertujuan untuk menghasilkan produk perencanaan pembelajaran bermuatan budaya lokal tepian sungai pada pendidikan anak usia dini dengan menggunakan prosedur research and development yang terdiri dari beberapa tahapan yaitu: analisis kebutuhan, pengembangan produk awal, uji ahli, revisi, dan uji lapangan. Berdasarkan hasil pengembangan produk telah memenuhi kriteria kevalidan, kepraktisan dan keefektifan. Hasil uji kevalidan sebesar 3,49 dengan kategori valid, uji kepraktisan sebesar 3,8 dengan kategori sedang, sedangkan uji keefektifan sebesar 97\%. Dengan demikian, dapat disimpulkan bahwa perencanaan pembelajaran bermuatan budaya lokal tepian sungai dapat digunakan dalam kegiatan pembelajaran di PAUD. Unsur kebaruan dalam penelitian ini yaitu perencanaan pembelajaran bermuatan budaya lokal tepian sungai yang sesuai dengan karakteristik pendidikan anak usia dini sehingga pembelajaran menjadi lebih menarik, bermakna serta menyenangkan.
\end{abstract}

Kata kunci: rencana pelaksanaan pembelajaran harian; budaya local; pendidikan anak usia dini

\begin{abstract}
This development research aims to produce learning planning products with local culture on the riverside in early childhood education using research and development procedures which consist of several stages of needs analysis, initial product development, expert testing, revision, and field testing. Based on the results of product development, it has met the criteria of validity, practicality, and effectiveness. The result of the validity test was 3.49 with the valid category, the practicality test was 3.8 with the medium category, while the effectiveness test was $97 \%$. Thus, it can be concluded that learning planning with local culture on the riverside can be used in learning activities in PAUD. The element of novelty in this research is learning planning that contains local culture on the riverside by the characteristics of early childhood education so that learning becomes more interesting, meaningful, and fun.
\end{abstract}

Keywords: learning planning; local culture; early childhood education

Copyright (c) 2021 Novitawati, Chresty Anggreani

$\triangle$ Corresponding author:

Email Address : chresty.anggreani@ulm.ac.id (Banjarmasin, Indonesia)

Received 19 September 2020, Accepted 25 November 2020, Published 17 April 2021 


\section{PENDAHULUAN}

Indonesia merupakan negara kepulauan terbesar di dunia yang terdiri dari 17.504 pulau. Sebagai negara kepulauan, Indonesia memiliki jumlah penduduk terbesar keempat di dunia dengan populasi 270.054.853 jiwa dan memiliki sekitar 300 etnis yang tersebar dan memiliki warisan kebudayaan yang berkembang dari berabad tahun yang lalu. Warisan kebudayaan tersebut beragam dan mempunyai kekhasan masing-masing yang memuat: nilai luhur, nilai kebaikan, teknologi, arsitektur, kesenian, dll. Berdasarkan Peraturan Menteri Pendidikan dan Kebudayaan Republik Indonesia Nomor 10 Tahun 2014 tentang Pedoman Pelestarian Tradisi Pasal 1 menyebutkan pelestarian tradisi adalah upaya perlindungan, pengembangan dan pemanfaatan suatu kebiasaan dari kelompok masyarakat pendukung kebudayaan yang penyebaran dan pewarisannya berlangsung secara turun temurun (Kemdikbud, 2014). Dengan demikian, untuk mencegah kepunahan tersebut, maka perlu dilakukan untuk pelestarian melalui pembuatan unsur budaya salah satunya melalui pendidikan.

Daerah Hulu Sungai Utara merupakan salah satu kabupaten yang berada di wilayah Kalimantan Selatan dengan wilayahnya yang terdiri dari dataran rendah dengan ketinggian berkisar antara 0-25 meter dari permukaan laut, sehingga menyebabkan daerah ini merupakan daerah rawa baik yang tergenang dengan menoton maupun tergenang secara periodic. Secara geografis Hulu Sungai Utara memiliki keunikan tersendiri, yang mana pada daerah ini banyaknya bangunan sekolah dibangunan diatas rawa. Dengan kekhasan tersebut, sudah seharusnya lembaga PAUD yang ada di daerah mengembangkan pembelajaran yang sesuai dengan keunikan tersebut melalui pembelajaran berbasis pada budaya lokal tepian sungai.

Pengertian budaya dipandang sebagai suatu cara hidup yang dimiliki oleh suatu kelompok masyarakat tertentu yang diwariskan dari generasi ke generasi (Rahmawati, 2015). Menurut (Musi et al., 2018) budaya lokal merupakan budaya pada suatu masyarakat tertentu yang memiliki ciri khas. Budaya lokal yang relevan dengan materi pelajaran dapat diintegrasikan dalam pembelajaran agar pembelajaran lebih bermakna bagi anak (Suardana \& Retug, 2017). (Lestariningrum \& Wijaya, 2019) menyebutkan pembelajaran anak usia dini sebagai upaya mengoptimalkan aspek-aspek perkembangan anak melalui materi-materi pada sumber belajar yang terdekat dengan anak terutama pada kearifan lokal yang dituangkan dalam menyusun rencana pembelajarannya. Dengan demikian, peran guru menjadi bagian penting dalam merancang pembelajaran yang memanfaatkan budaya lokal dalam lingkungan alamiah sebagai sumber belajarnya. Sehingga pembelajaran berbasis budaya lokal di PAUD sangat sesuai dikembangkan di PAUD sebagai bentuk pelestarian pada budaya lokal. Prinsipprinsip pembelajaran berbasis budaya lokal pada anak usia dini, yaitu: 1) proses pembelajaran berdasarkan budaya lokal pada anak usia dini didasarkan pada prinsip-prinsip pengembangan anak, 2) pembelajaran berdasarkan budaya lokal pada anak usia dini dilaksanakan berdasarkan prinsip belajar melalui bermain, 3) proses belajar berdasarkan budaya lokal pada anak usia dini dilaksanakan dalam lingkungan yang kondusif dan inovatif, 4) pembelajaran berbasis budaya lokal pada anak usia dini dilaksanakan dengan pendekatan tematik terpadu, 5) pembelajaran berdasarkan budaya lokal pada anak usia dini diarahkan pada pengembangan potensi kecerdasan menyeluruh dan terpadu ((Muzakki \& Fauziah, 2015).

Perencanaan Pembelajaran adalah proyeksi tentang sesuatu yang akan dilakukan oleh guru dalam belajar mengajar (Nadlir, 2013). Proses pembelajaran akan berhasil jika seorang guru mampu memahami perencanaan pembelajaran dengan baik (Apriyanti, 2017). Pada ((Peraturan Menteri Pendidikan Dan Kebudayaan Republik Indonesia Nomor 146 Tahun 2014 Tentang Kurikulum 2013 Pendidikan Anak Usia Dini, 2014)) disebutkan bahwa rencana pelaksanaan pembelajaran harian merupakan acuan pembelajaran harian yang disusun oleh guru. (Hamdayama, 2016, p. 21) mendefinisikan rencana pelaksanaan pembelajaran (RPPH) sebagai kurikulum mikro yang menggambarkan tujuan atau kompetensi, materi atau isi 
pembelajaran, kegiatan pembelajaran, dan alat evaluasi yang digunakan. Jadi, rencana pelaksanaan pembelajaran harian (RPPH) merupakan pedoman pembelajaran dalam satu kali pertemuan yang memuat tujuan, pendekatan, metode pembelajaran, kegiatan pembelajaran dan penilaian yang digunakan.

Peran guru dalam kegiatan pembelajaran dimulai dari merencanakan, melaksanakan, dan melakukan penilaian terhadap hasil belajar. (Wuryandani, 2010) mengungkapkan guru dalam melaksanakan pembelajaran harus memanfaatkan nilai kearifan lokal sebagai sumber belajar yang diintegrasikan dalam pembelajaran. Implikasi budaya lokal dalam pembelajaran diterapkan dalam tema, subtema, materi atau kegiatan, APE, media, dan peralatan yang mengacu pada unsur-unsur kebudayaan di lingkungan sekitar anak tinggal (Widiastuti, 2012). Rencana pelaksanaan pembelajaran harian (RPPH) yaitu perencanaan kegiatan harian yang dilaksanakan oleh pendidik setiap hari sesuai dengan program yang telah ditentukan lembaga PAUD (Pamungkas et al., 2016). Hal ini senada dengan pendapat yang dikemukakan oleh (Musi et al., 2018) bahwa pendidikan anak usia dini memberi kesempatan kepada anak untuk mengembangkan kepribadiannya sehingga pentingnya menyediakan berbagai kegiatan yang dapat mengembangkan seluruh aspek perkembangannya.

Berdasarkan studi dokumentasi pada dokumen perencanaan pembelajaran yang dibuat oleh guru di TK Mentari KD Kab. Hulu Sungai Selatan ditemukan perencanaan pembelajaran yang digunakan oleh guru belum memuat unsur-unsur budaya lokal tepian sungai yang terlihat dari guru belum memanfaatkan benda-benda disekitar dan lingkunganya sebagai sumber belajar dalam menunjang kegiatan pembelajaran. Dari hasil wawancara dengan guru penyebab para guru belum memuat unsur-unsur budaya lokal dikarenakan: 1) latar belakang Pendidikan para guru bukan dari Sarjana Pendidikan Guru Pendidikan Anak Usia Dini / S1 PGPAUD, 2) belum ada perencanaan pembelajaran yang memuat budaya lokal tepian sungai, 3) keterbatasan pengetahuan guru. Tujuan pengenalan kebudayaan pada anak usia dini adalah agar anak dekat dengan lingkunganya, dan untuk membekali anak hidup pada masa masa sekarang, dan bekal untuk hidup di kemudian hari dimasyarakat (Widiastuti, 2012). Sehingga guru harus mampu mengembangkan pembelajaran yang sesuai dengan lingkungan alamiah anak memiliki muatan budaya lokal.

Penelitian ini bertujuan untuk1) mengembangkan perencanaan pembelajaran berbasis budaya lokal tepian sungai, 2) mengetahui kevalidan perencanaan pembelajaran berbasis budaya lokal tepian sungai, 3) mengetahui kepraktisan serta keefektifan produk perencanaan pembelajaran yang dikembangkan untuk meningkatkan kualitas pembelajaran di PAUD.

\section{METODOLOGI}

Jenis penelitian yang digunakan dalam penelitian ini adalah penelitian dan pengembangan (research and development). (Sudaryono, 2016, p. 15) menyebutkan penelitian dan pengembangan adalah metode penelitian yang digunakan untuk menghasilkan produk tertentu, dan menguji keefektifan produk tersebut. Hal serupa juga diungkapkan oleh (Sugiyono, 2016, p. 297) penelitian pengembangan adalah metode penelitian yang digunakan untuk menghasilkan produk tertentu, dan menguji keefektifan produk tersebut. Model pengembangan yang digunakan dalam pengembangan rencana pelaksanaan pembelajaran harian (RPPH) berbasis budaya lokal tepian sungai mengadaptasi model pengembangan ADDIE (Analysis, Design, Development, Implementation, Evaluation) (Pribadi, 2009). Prosedur penelitian dapat dilihat pada gambar 1.

Tahap pengembangan dari bagan diatas yaitu: 1) tahap analisis (analysis), merupakan kegiatan analisis kebutuhan yang bertujuan untuk mengetahui perencanaan pembelajaran yang digunakan oleh sekolah, kemudian dilanjutkan dengan analisis kurikulum dengan mengidentifikasi kompetensi inti dan kompetensi dasar untuk menentukan tujuan pembelajaran yang sesuai materi yang memuat unsur-unsur budaya lokal tepian sungai. 2) tahap perancangan (design), pada tahap ini peneliti merancang perencanaan pembelajaran berbasis budaya lokal tepian sungai. Kegiatan penyusunan ini dilakukan secara sistematis 
yang diawali dengan menuliskan identitas, menentukan tujuan pembelajaran, merancang materi pembelajaran, menentukan metode pembelajaran yang sesuai, merancang Langkahlangkah pembelajaran mulai dari kegiatan pembukaan, kegiatan inti, dan kegiatan penutup, memilih sumber belajar yang tepat, dan merancang penilaian pembelajaran. 3) tahap pengembangan (development), setelah produk awal yang telah disusun berupa perencanaan pembelajaran berbasis budaya lokal tepian sungai, langkah selanjutnya adalah validasi ahli untuk mendapatkan masukan dan saran terhadap produk yang telah dikembangkan. 4) tahap implementasi (implementation), Produk yang telah dinyatakan valid oleh ahli dan layak untuk digunakan dalam kegiatan pembelajaran kemudian dicetak dan diperbanyak untuk diimplementasikan secara terbatas dalam kegiatan pembelajaran di kelompok B di TK Mentari KD. 5) tahap evaluasi (evaluation), kegiatan evaluasi yang dilakukan berupa evaluasi terhadap kevalidan, kepraktisan, dan keefektifan produk perencanaan pembelajaran berbasis budaya lokal tepian sungai yang telah dikembangkan.

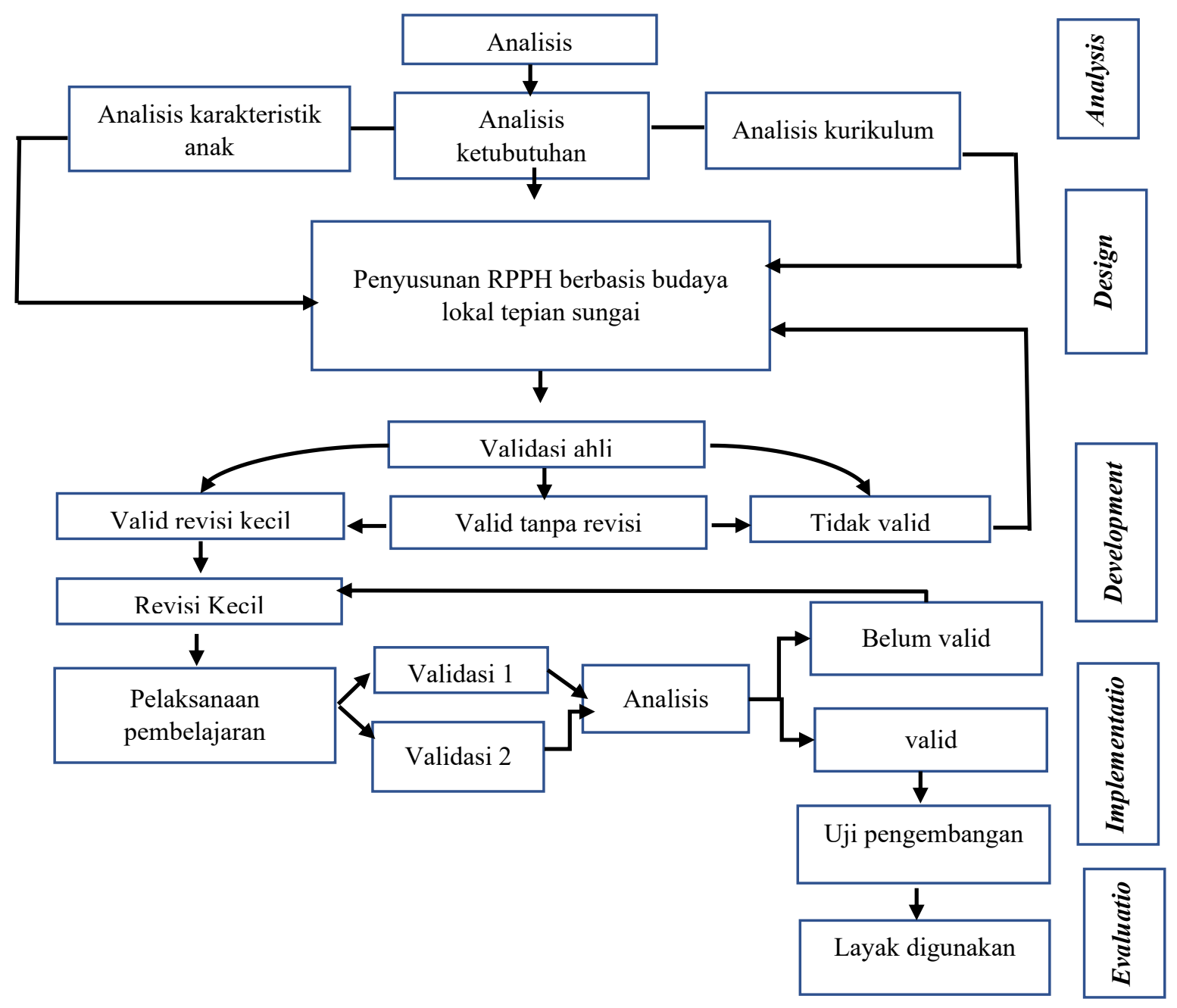

Gambar 1. Model Pengembangan 4D

Responden dalam penelitian ini adalah Kepala Sekolah dan guru, dan anak kelompok B di TK Mentari KD. Alat pengumpul data yang digunakan yaitu wawancara, angket, dan lembar observasi. Wawancara digunakan untuk analisis kebutuhan produk yang dikembangkan, sedangkan angket digunakan untuk validasi ahli. Angket untuk validasi ahli terdiri dari: 1) format $\mathrm{RPPH}$, 2) Isi RPPH, 3) Penilaian, 4) Waktu, 5) Bahasa dan Tulisan. Lembar observasi digunakan untuk melihat keterlaksanaan RPPH berbasis budaya lokal tepian sungai dalam kegiatan pembelajaran. Aspek keterlaksanaan terdiri atas: 1) kegiatan pembukaan, kegiatan inti, dan penutup. 


\section{HASIL DAN PEMBAHASAN}

Hasil penelitian dan pengembangan ini berupa model pelaksanaan pembelajaran harian (RPPH) taman kanak-kanak berbasis budaya lokal tepian sungai. Penelitian ini menggunakan metode yang dikembangkan model ADDIE yang terdiri dari tahap analysis (analisis), design (desain), development (pengembangan), implementation (implementasi), dan evaluation (evaluasi). Selengkapnya pada tabel 1.

Tabel 1. Tahapan penelitian dengan model ADDIE

\begin{tabular}{|c|c|}
\hline Tahapan & Proses Penelitian \\
\hline $\begin{array}{l}\text { Tahap Analisis } \\
\text { (Analysis) }\end{array}$ & $\begin{array}{l}\text { Tahap analisis ini terdiri dari analisis kebutuhan, analisis karakteristik anak, dan } \\
\text { analisis kurikulum. Berdasarkan pengamatan yang peneliti lakukan di TK } \\
\text { Mentari KD yang terletak di tepian sungai terlihat rencana pelaksanaan } \\
\text { pembelajaran harian (RPPH) yang belum sesuai dengan pelaksanaan kegiatan } \\
\text { pembelajaran. Dalam kegiatan pembelajaran guru belum melibatkan anak secara } \\
\text { aktif sehingga pembelajaran kurang menarik. Kegiatan pembelajaran lebih } \\
\text { berfokus kepada calistung. Bahan ajar yang digunakan berupa lembar kerja } \\
\text { peserta didik (LKPD), akan tetapi LKPD yang digunakan tidak sesuai dengan } \\
\text { RPPH yang dibuat guru. LKPD yang digunakan guru tidak mencerminkan tema- } \\
\text { tema yang sesuai dengan budaya lokal lingkungan sekitar. Sedangkan dari hasil } \\
\text { wawancara dengan guru, guru sangat membutuhkan RPPH yang sesuai dengan } \\
\text { lingkungan tempat tinggal mereka, yaitu budaya tepian sungai. Selama ini, RPPH } \\
\text { yang dibuat guru berdasarkan hasil diskusi antar guru di sekolah tersebut } \\
\text { berpedoman pada program semester yang didapat dari gugus. Berdasarkan hasil } \\
\text { studi dokumentasi dokumen RPPH yang dimiliki sekolah, belum mengacu pada } \\
\text { kurikulum } 2013 \text { dan tidak jelasnya tujuan pembelajaran yang akan dicapai dalam } \\
\text { setiap pembelajaran. Oleh karena itu, berdasarkan analisis kebutuhan bahwa } \\
\text { format RPPH berbasis budaya lokal tepian sungai sangat diharapkan oleh guru- } \\
\text { guru TK KD Mentari yang terletak di tepian sungai. }\end{array}$ \\
\hline $\begin{array}{l}\text { Tahap desain } \\
(\text { design })\end{array}$ & $\begin{array}{l}\text { Tahapan desain merupakan tahapan perancangan produk yang dikembangkan. } \\
\text { Desain yang dilakukan yaitu membuat rancangan rencana pelaksanaan } \\
\text { pembelajaran harian (RPPH), lembar kerja peserta didik, dan perencanaan } \\
\text { penilaian pembelajaran }\end{array}$ \\
\hline $\begin{array}{l}\text { Tahap } \\
\text { Pengembangan } \\
\text { (development) }\end{array}$ & $\begin{array}{l}\text { Pada tahap pengembangan disusun rencana pelaksanaan pembelajaran harian } \\
\text { berbasis budaya lokal tepian sungai mulai dari pengidentifikasian tema dan } \\
\text { subtema, penyusun program semester } 1 \text { dan program semester 2, rencana } \\
\text { pelaksanaan pembelajaran mingguan (RPPM), rencana pelaksanaan } \\
\text { pembelajaran harian (RPPH), pembuatan LKPD, dan penyusunan perangkat } \\
\text { penilaian harian. Penulisan ini dilakukan dengan menggunakan Microsoft Word } \\
2016\end{array}$ \\
\hline $\begin{array}{l}\text { Tahap } \\
\text { implementasi } \\
\text { mplementation) }\end{array}$ & $\begin{array}{l}\text { Tahap implementasi pada penelitian ini merupakan proses uji coba produk RPPH } \\
\text { berbasis budaya lokal tepian sungai. RPPH ini diimplementasikan pada } \\
\text { kelompok B Taman Kanak-Kanak Mentari KD, Hulu Sungai Selatan yang berada } \\
\text { di tepian sungai. Uji coba dilaksanakan sebanyak } 4 \text { (empat) kali pertemuan mulai } \\
\text { dari tanggal 13, 16, 20, } 23 \text { Januari } 2020 \text { yang diikuti sebanyak } 20 \text { anak }\end{array}$ \\
\hline
\end{tabular}

Pelaksanaan uji coba RPPH melalui 3 tahapan yaitu; validasi, hasil validasi, dan uji coba. Rincian pelaksanaan pada paragraf berikut.

Validasi: Penentuan kriteria baik atau tidaknya suatu RPPH adalah dengan menggunakan hasil validasi oleh para ahli. Para ahli diminta untuk memvalidasi RPPH berbasis budaya lokal tepian sungai yang telah dihasilkan pada tahap perancangan. Selanjutnya saran-saran dari para validator digunakan sebagai pedoman dalam melakukan revisi RPPH sehingga diperoleh prototipe II. Aspek RPPH yang diamati meliputi: 1) Format $\mathrm{RPPH}$, 2) Isi RPPH, 3) Penilaian, 4) Waktu, 5) Bahasa dan Tulisan. Validator dalam penelitian ini terdiri dari dua orang yaitu: 1) Dr. Metroyadi, M.Pd, sebagai tim pengembangan 
Pengembangan Perencanaan Pembelajaran Bermuatan Budaya Lokal Tepian Sungai pada Anak Usia Dini DOI: 10.31004/obsesi.v6i1.767

kurikulum di lingkungan universitas Lambung Mangkurat 2) Lisnawati, M.Pd sebagai pengawas PAUD di Provinsi Kalimantan Selatan.

Hasil Validasi: Aspek-aspek yang diperhatikan dalam memvalidasi RPH yaitu: format $\mathrm{RPPH}$, Isi RPPH, 3) Penilaian, 4) Waktu, 5) Bahasa dan Tulisan. Hasil validasi ahli dapat dirangkum pada tabel 3.

Tabel 3. Rangkuman Hasil Validasi RPPH

\begin{tabular}{llll}
\hline No & Aspek Penilaian & Hasil Penilaian & Kategori \\
\hline $\mathbf{1}$ & Format RPPH & 4 & Sangat Valid \\
$\mathbf{2}$ & Isi RPPH & 3,68 & Sangat Valid \\
$\mathbf{3}$ & Penilaian & 3 & Valid \\
$\mathbf{4}$ & Waktu & 3,75 & Sangat Valid \\
$\mathbf{5}$ & Bahasa dan Tulisan & 3 & Valid \\
\hline Rata-rata & 3,49 & Valid \\
\hline
\end{tabular}

Berdasarkan pada tabel diatas menunjukan bahwa nilai rata-rata kevalidan RPPH berada pada kategori valid berada pada rentang $(2,5 \leq \mathrm{V}<3,5)$. Penilaian secara umum oleh para ahli untuk RPPH adalah baik dan layak untuk digunakan/ diujicobakan dengan revisi.

Uji Coba: RPPH yang telah direvisi berdasarkan masukan dari validator, langkah selanjutnya adalah melakukan uji coba produk dalam kegiatan pembelajaran yang dilaksanakan oleh guru. Jumlah peserta didik dalam kegiatan ujicoba in berjumlah 18 orang dan 2 orang guru yang terdiri dari guru utama dan guru pendamping. Pengujicobaan RPPH dimaksudkan untuk menyempurnakan RPPH yang telah dikembangkan. Kegiatan ujicoba ini dilakukan dalam dua tahapan yaitu tahapan pra ujicoba dan tahapan uji coba.

\section{Tahapan Pra Uji Coba}

Sebelum dilakukan uji coba RPPH dalam kegiatan pembelajaran, terlebih dahulu dilakukan FGD (forum Group Discussion) yaitu pertemuan khusus dengan guru yang akan menjadi model dalam pelaksanaan RPPH berbasis budaya lokal tepian sungai dalam kegiatan pembelajaran. Kegiatan ini dilaksanakan pada tanggal 10 Januari 2020. Guru dalam penelitian ini adalah Mardiah, S.Pd yang juga sebagai guru utama kelompok B TK Mentari KD, guru utama akan didampingi oleh guru pendamping yaitu Lisda. Untuk pengamat uji coba dalam penelitian ini terdiri dari terdiri dari 2 (dua) orang guru yaitu: Rina S.Pd.I dan Safariyanti, S.Pd.I. Setelah guru model, guru pendamping, dan pengamat berkumpul, peneliti menjelaskan tujuan dari penelitian yang dilakukan. Kemudian peneliti menjelaskan dan mensimulasikan RPPH yang dikembangkan kepada guru model, guru pendamping, dan observer. Peneliti juga menjelaskan kepada observer tata cara mengisi lembar observasi keterlaksanaan RPPH. Peneliti menjelaskan kepada guru model dan guru pendamping tentang cara pelaksanaan pembelajaran menggunakan RPPH yang telah dikembangkan untuk 3 (tiga) kali pertemuan. Hasil dari tahap ini diperoleh saran dan masukan secara langsung dai guru model untuk bekal tahap uji coba sesungguhnya di kelas yang telah ditentukan.

\section{Tahap Uji Coba}

Pelaksanaan uji coba RPPH berbasis budaya lokal tepian sungai dilaksanakan di Taman Kanak-Kanak Mentari KD, Kab. Hulu Sungai Selatan yang terletak di tepian sungai dengan jumlah peserta didik sebanyak 18 orang. Ujicoba ini dilaksanakan selama empat pertemuan yang mengimplementasi dari RPPH yang telah dikembangkan. Dalam uji coba ini mengambil subtema alat transportasi dikarenakan mengikuti tema pembelajaran yang sedang dilaksanakan di sekolah tersebut. Kegiatan ujicoba ini bertujuan untuk mengetahui keterlaksanaan, kepraktisan, dan keefektifan RPPH yang dikembangkan. Tabel 4 dan gambar 1-5 adalah jadwal pelaksanaan dan dokumentasi kegiatan uji coba. 
Tabel 4. Jadwal Uji Coba Pelaksanaan Penelitian

\begin{tabular}{lll}
\hline No & \multicolumn{1}{c}{ Materi } & \multicolumn{1}{c}{ Pelaksanaan } \\
\hline 1 & RPPH alat transportasi darat/ sepeda & 13 Januari 2020 \\
2 & RPPH alat transportasi darat/ mobil & 16 Januari 2020 \\
3 & RPPH alat transportasi air/ jukung & 20 Januari 2020 \\
4 & RPPH alat transportasi udara/ pesawat terbang & 23 Januari 2020 \\
\hline
\end{tabular}

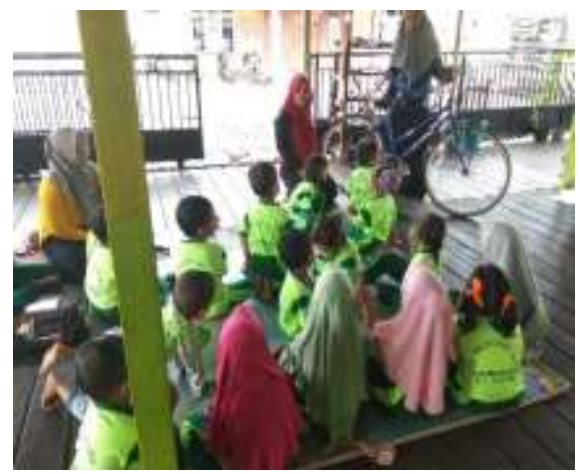

Gambar 1. Kegiatan Pembelajaran Alat Transportasi/Sepeda

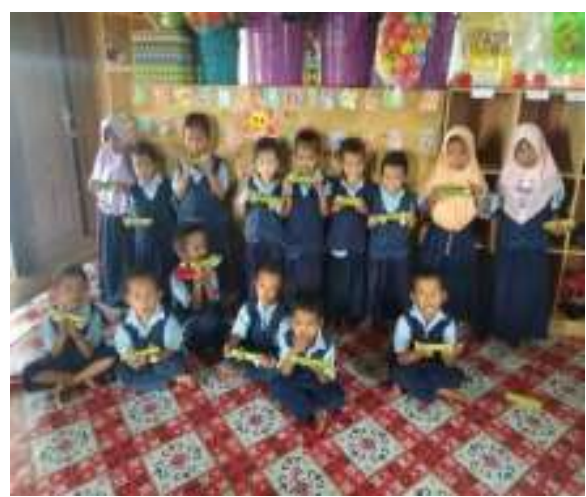

Gambar 3. Anak Membuat Miniatur Mobil-Mobilan dari Pelepah Pisang

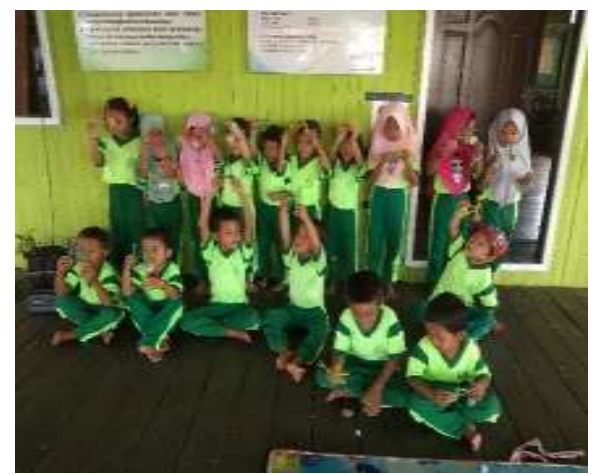

Gambar 2. Anak Membuat Miniatur Sepeda

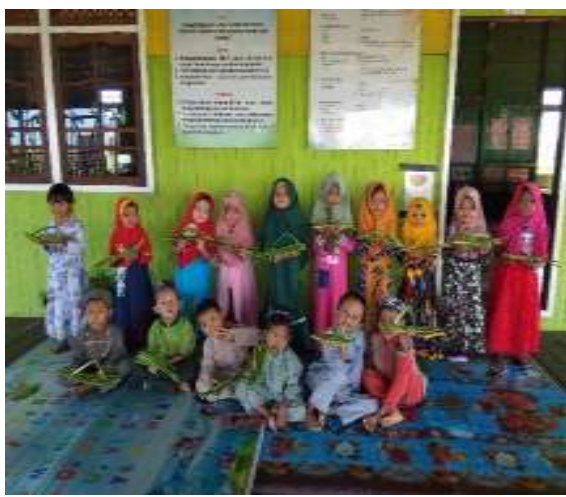

Gambar 4. Anak Membuat Miniatur Kapal-Kapalan dari Pelepah Eceng Gondok

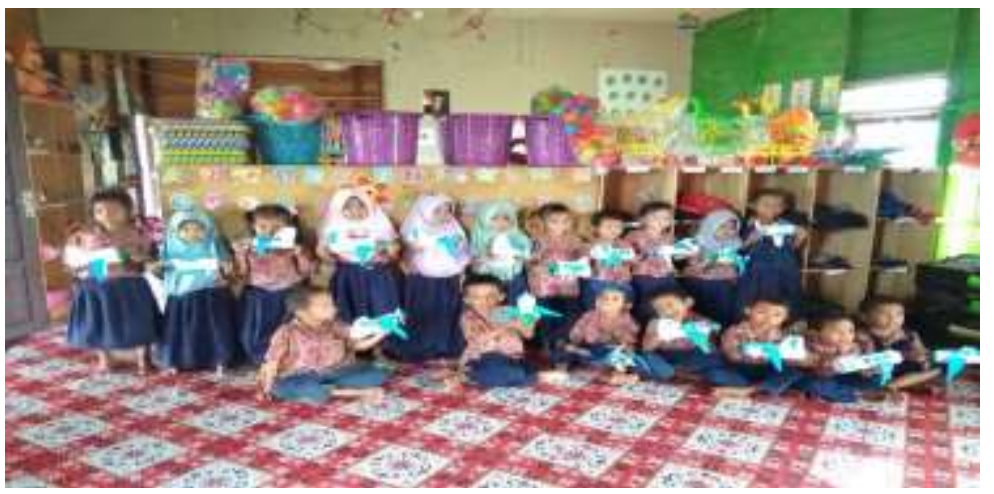

Gambar 5. Anak Membuat Miniatur Pesawat Terbang dari Botol Bekas

\section{Tahap evaluasi (evaluation)}

Tahap evaluasi digunakan untuk mengetahui apakah rencana pelaksanaan pembelajaran harian (RPPH) yang telah dibuat layak atau tidak layak untuk digunakan dalam kegiatan pembelajaran. Evaluasi yang telah dilakukan terhadap RPPH yang dikembangkan dengan berbasis muatan budaya lokal tepian sungai yang meliputi; 
Kualitas Kevalidan: Penilaian kevalidan RPPH berbasis budaya lokal tepian sungai dilakukan oleh validator. Penilaian produk yang dilakukan oleh validator yaitu kevalidan $\mathrm{RPPH}$ Berbasis Tepian Sungai. Adapun aspek yang nilai dalam uji kevalidan ini yaitu: 1) format $\mathrm{RPPH}, 2$ ) isi $\mathrm{RPH}, 3$ ) penilaian, 4) waktu, 5) bahasa dan tulisan.

Kualitas Kepraktisan: Penilaian kualitas kepraktisan dapat dilihat menggunakan angket respon guru dan lembar observasi.

Respon guru: Analisis perhitungan data dari rata-rata skor angket guru adalah sebesar 3,5 dengan kategori sangat baik. Berdasarkan kriteria kepraktisan angket respon guru, menunjukan bahwa RPPH berbasis budaya lokal tepian sungai memiliki nilai praktis.

Lembar observasi: Pembelajaran berlangsung sebanyak 4 (empat) pertemuan. Dalam setiap pertemuan dilakukan observasi pembelajaran. Observasi ini dilaksanakan untuk mengetahui kepraktisan RPPH berbasis budaya lokal tepian sungai yang dikembangkan. Hasil perhitungan lembar observasi pada tabel 5.

Tabel 5. Rekapitulasi Pengamatan Keterlaksanaan RPPH

\begin{tabular}{cccc}
\hline No & Pertemuan ke- & Rata-Rata Nilai & Keterangan \\
\hline $\mathbf{1}$ & Pembelajaran pertemuan pertama & 3,3 & Terlaksana \\
$\mathbf{2}$ & Pembelajaran pertemuan kedua & 3,6 & Terlaksana \\
$\mathbf{3}$ & Pembelajaran pertemuan ketiga & 3,7 & Terlaksana \\
$\mathbf{4}$ & Pembelajaran pertemuan keempat & 3,86 & Terlaksana \\
\hline & Rata-rata Total & $\mathbf{3 , 6}$ & Terlaksana \\
\hline
\end{tabular}

Pada tabel 5 menunjukan bahwa rata-rata total keterlaksanaan RPPH berbasis budaya lokal tepian sungai pada pertemuan pertama yaitu sebear 3,3, pertemuan kedua sebesar 3,6, pertemuan ketiga sebesar 3,7, dan pertemuan keempat sebesar 3,86. Hal ini berarti ada peningkatan hasil keterlaksanaan yang dicapai guru selama proses pembelajaran menggunakan RPPH berbasis budaya lokal tepian sungai yang dikembangkan.

Data analisis hasil belajar anak setelah mengikuti pembelajaran menggunakan RPPH berbasis budaya lokal tepian sungai pada tabel diatas menunjukan bahwa ketuntasan anak dalam kegiatan pembelajaran tersebut adalah yang berada minimal pada klasifikasi kriteria baik. Keefektifan produk yang dikembangkan dilakukan melalui ketuntasan belajar. Berdasarkan pada tabel diatas pada pertemuan pertama, persentase ketuntasan anak dalam kegiatan pembelajaran berdasarkan RPPH yang dikembangkan sebesar 94,11\% dengan kriteria sangat baik, nilai tertinggi sebesar 91,7 dan nilai terendah sebesar 45,8. Pada pertemuan kedua persentase ketuntasan anak dalam kegiatan pembelajaran yaitu sebesar 94,11\% dengan kriteria sangat baik, nilai tertinggi sebesar 100 dan terendah 54,1. Dan pada pertemuan ketiga persentase ketuntasan anak adalah 100\% berada pada kriteria sangat baik, nilai tertinggi sebesar 95,8 dan nilai terendah 79,1. Sedangkan pada pertemuan keempat persentase ketuntasan anak sebesar $100 \%$ dengan kriteria sangat baik, dengan nilai tertinggi sebesar 100 dan nilai terendah 66,7.

Tabel 6. Rata-Rata Hasil Pembelajaran Pada Setiap Pertemuan dalam Pengembangan RPPH Berbasis Budaya Lokal Tepian Sungai

\begin{tabular}{lccc}
\hline & Pertemuan Ke & Rata-rata Hasil Belajar Anak & Ketegori \\
\hline $\mathbf{1}$ & Pertemuan ke 1 & 74,5 & BSH \\
$\mathbf{2}$ & Pertemuan ke 2 & 80,3 & BSB \\
$\mathbf{3}$ & Pertemuan ke 3 & 84,3 & BSB \\
$\mathbf{4}$ & Pertemuan ke 4 & 86 & BSB \\
\hline
\end{tabular}

Rata-rata hasil belajar anak dalam setiap pertemuan setelah mengikuti pembelajaran menggunakan RPPH berbasis budaya lokal tepian sungai menunjukan bahwa rata-rata-rata 
nilai hasil belajar anak pada pertemuan pertama sebesar 74,5 berada pada kategori berkembang sesuai harapan (BSH). Pada pertemuan kedua rata-rata nilai hasil belajar anak yaitu sebesar 80,3 berada pada kategori berkembang sangat baik (BSB), dan pada pertemuan ketiga nilai rata-rata hasil belajar anak yaitu 84,3 dengan kategori berkembang sangat baik (BSB). Sedangkan rata-rata nilai hasil belajar anak pada pertemuan keempat yaitu sebesar 86 dengan kategori berkembang sangat baik (BSB). Selengkapnya dapat dilihat pada tabel 6.

\section{Pembahasan}

Berdasarkan data dari uji coba yang telah dilakukan selama 4 (empat) kali pertemuan digunakan untuk melihat sejauh mana RPPH berbasis budaya lokal tepian sungai yang telah dikembangkan memenuhi kriteria kevalidan, kepraktisan, dan keefektifan. Dan juga akan dibahasa kendala-kendala yang dihadapi peneliti selama kegiatan penelitian.

Rencana pelaksanaan pembelajaran harian berbasis budaya lokal tepian sungai yang telah dikembangkan digunakan dalam proses pembelajaran setelah melalui tahap validasi. Uji kevalidan RPPH berbasis budaya lokal tepian sungai dilakukan oleh dua orang ahli yang masing-masing memberi penilaian pada lembar validasi terhadap produk RPPH yang telah dikembangkan oleh peneliti. Rata-rata penilaian validator terhadap RPPH yang terdiri dari aspek 1) format RPPH, 2) isis RPPH, 3) Penilaian, 4) waktu, 5) bahasa dan tulisan yaitu sebesar 3,49 dengan kategori valid. Dengan demikian berdasarkan pada penilaian validator RPPH berbasis budaya lokal yang dikembangkan dapat diterapkan secara langsung dalam kegiatan pembelajaran dengan memperhatikan beberapa saran dan perbaikan yang dikemukakan oleh validator untuk diperbaiki sehingga menjadi bentuk RPPH yang lebih baik. Jadi, ditinjau berdasarkan pada keseluruhan aspek dalam RPPH berbasis budaya lokal tepian sungai dinyatakan memenuhi kriteria kevalidan dan layak digunakan dalam kegiatan pembelajaran. Hasil revisi dari kegiatan validasi pada produk RPPH berbasis budaya lokal tepian sungai tersebut adalah perangkat draf kedua yang akan digunakan pada tahap uji coba produk.

Peninjauan aspek kepraktisan dilakukan dengan menggunakan hasil lembar observasi pelaksanaan pembelajaran, lembar observasi anak dalam kegiatan pembelajaran dan hasil angket guru, RPPH berbasis budaya lokal tepian sungai yang telah dikembangkan praktis untuk digunakan dengan persentase rata-rata keterlaksanaan pembelajaran selama empat kali pertemuan sebesar 3,86, dengan kriteria sedang. Rata-rata keterlaksanaan pembelajaran pada kegiatan ini sebesar 3,8 dengan kriteria sedang. Rata-rata keterlaksanaan pembelajaran pada kegiatan inti adalah sebesar 3,8 dengan kriteria sedang. Sedangkan ratarata keterlaksanaan pembelajaran pada kegiatan penutup sebesar 4 dengan kriteria tinggi.

Keefektifan dari rencana pelaksanaan pembelajaran harian (RPPH) berbasisi budaya lokal tepian sungai yang dikembangkan dapat dilihat dari penilaian hasil belajar anak. Penilaian ini memuat enam bidang perkembangan anak yang meliputi: aspek perkembangan nilai, agama dan moral, aspek perkembangan sosial emosional, aspek perkembangan bahasa, aspek perkembangan kognitif, aspek perkembangan fisik motorik, dan aspek perkembangan seni. Penilaian anak didasarkan pada tujuan pembelajaran dalam RPPH pada setiap pertemuannya. Penilaian hasil belajar ini dilihat dari pertemuan satu, pertemuan kedua, pertemuan ketiga, dan pertemuan keempat. Hasil penilaian ini kemudian dianalisis dan dideskripsikan untuk mengetahui ketuntasan kegiatan pembelajaran.

Dari hasil analisis deskriptif diperoleh rata-rata nilai pada pertemuan pertama sebesar 74,5 dengan kategori berkembang sesuai harapan (BSH). Ketuntasan belajar pada pertemuan pertama sebesar $94,11 \%$ berada pada kategori sangat tinggi. Pada pertemuan kedua rata-rata nilai sebesar 80,3 dengan kategori berkembang sangat baik (BSB). Pada pertemuan kedua ini, ketuntasan belajar sebesar $94,11 \%$ berada pada kategori sangat tinggi. Pada pertemuan ketiga, rata-rata nilai sebesar 84,3 berada pada kategori berkembang sangat baik (BSB) dengan ketuntasan belajar sebesar 100\% kategori sangat tinggi. Sedangkan pada pertemuan keempat, rata-rata nilai sebesar 86 berada rentang kategori berkembang sangat baik (BSB) dengan ketuntasan belajar sebesar $100 \%$ kategori sangat tinggi. Berdasarkan pada hasil dianalisis 
diatas bahwa RPPH berbasis budaya lokal tepian sungai efektif digunakan dalam proses pembelajaran.

Hasil akhir dari penelitian ini berupa perencanaan pembelajaran berbasis budaya lokal tepian sungai untuk mewujudkan pembelajaran di PAUD yang sesuai dengan kebutuhan anak sebagaimana yang diungkapkan oleh (Suastra, 2010) bahwa lingkungan alamiah dan sosial merupakan sumber belajar bagi anak yang dapat dimanfaatkan oleh guru dalam merancang pembelajaran sesuai dengan materi pembelajaran. Seorang guru PAUD harus mampu menyusun perencanaan pembelajaran dengan baik sesuai kebutuhan anak, seperti yang diungkap oleh (Hamalik, 2015, p. 143) prinsip-prinsip dalam merancang perencanaan pembelajaran terdiri atas: 1) perumusan tujuan harus jelas, 2) memilih dan menyusun bahanbahan instruksional dengan baik untuk pencapain tujuan, 3) menentukan metode mengajar yang bervariasi, 4) petunjuk jumlah waktu yang disediakan dalam kegiatan pembelajaran, 5) aplikasi-aplikasi bahan didalam maupun diluar, 6) sumber belajar dan pelengkap, 7) evaluasi pembelajaran, 8) Saran untuk revisi rencana, sesudah dilaksanakan. (Jannah, 2017) menyebutkan RPPH yang telah dibuat oleh guru dengan baik, hendaknya juga dilaksanakan guru dengan baik untuk pencapaian tujuan yang baik pula. Pemuatan unsur kearifan lokal dalam kegiatan pembelajaran anak usia dini bermanfaat untuk mengembangkan karakter, mengembangkan nilai kasih sayang dan gotong royong, mengembagkan kecerdasan emosi, dan mengembangkan kecerdasan logika matematika anak (Hapidin \& Yenina, 2016), (Yetti \& Juniasih, 2016), (Lubis \& Khadijah, 2018),(Lestariningrum \& Handani, 2017),(Yani \& Timur, 2017). Dengan demikian, penerapan unsur dalam budaya lokal dalam pembelajaran merupakan sebagai perwujudan penanaman rasa cinta anak terhadap budaya daerah sendiri dan sebagai untuk pelestarian budaya.

Penelitian dan pengembangan perencanaan pembelajaran berbasis budaya tepian sungai ini tidaklah sempurna, yang memiliki keterbatasan-keterbatasan. Adapun kelebihan dari perencanaan pembelajaran berbasis budaya lokal tepian sungai yaitu: 1) perencanaan pembelajaran yang dibuat berdasarkan pada tema-tema yang berada dilingkungan tepian sungai, 2) materi yang dipilih sesuai dengan karakteristik anak usia dan mengacu pada materi yang mencakup pada budaya lokal tepian sungai,3) mewujudkan pembelajaran yang menarik dan menyenangkan.

\section{SIMPULAN}

Penelitian dan pengembangan ini menghasilkan produk berupa perencanaan pembelajaran berbasis budaya lokal tepian sungai telah memenuhi kriteria kevalidan, kepraktisan dan keefektifan yang sesuai dengan pembelajaran anak usia dini. Perencanan pembelajaran ini terdiri dari: RPPH, lembar kerja peserta didik, dan lembar penilaian. Perencanaan pembelajaran ini dapat digunakan pada daerah yang memiliki kesamaan dan keunikan lingkungan tepian sungai. Pengenalan budaya kepada anak harus dikenalkan sedini mungkin agar anak tidak merasa asing dengan budaya sendiri. Kegiatan pelestarian budaya lokal tepian sungai ini dapat dimulai pada jenjang PAUD yang diintegrasikan dalam kegiatan pembelajaran.

\section{UCAPAN TERIMA KASIH}

Penelitian ini dapat terlaksana dengan baik karena adanya bantuan dari berbagai pihak. Untuk itu peneliti mengucapkan terima kasih kepada Bapak Rektor Universitas Lambung Mangkurat, dan Bapak Dekan Fakultas Keguruan dan Ilmu Pendidikan Universitas Lambung Mangkurat, LPPM Universitas Lambung Mangkurat, Mahasiswa PG-PAUD Universitas Lambung Mangkurat dan TK Mentari Ceria di Kab. Hulu Sungai Selatan yang telah bekerjasama dan membantu peneliti dalam melaksanakan penelitian ini dengan baik. Peneliti juga mengucapkan terima kasih kepada redaktur dan reviewer Jurnal Obsesi: Jurnal Pendidikan Anak Usia Dini yang telah memuat hasil penelitian ini. 


\section{DAFTAR PUSTAKA}

Apriyanti, H. (2017). Pemahaman Guru Pendidikan Anak Usia Dini Terhadap Perencanaan Pembelajaran Tematik. Jurnal Obsesi: Jurnal Pendidikan Anak Usia Dini, 1(2), 111-117. https://doi.org/10.31004/obsesi.v1i2.22

Hamalik, O. (2015). Proses Belajar Mengajar. Bumi Aksara.

Hamdayama, J. (2016). Metodologi Pengajaran. Jakarta: Bumi Aksara.

Hapidin, H., \& Yenina, Y. (2016). Pengembangan Model Permainan Tradisional Dalam Membangun Karakter Anak Usia Dini. Jpud - Jurnal Pendidikan Usia Dini, 10(2), 201-212. https://doi.org/10.21009/jpud.102.01

Jannah, M. (2017). Kemampuan Guru Paud Dalam Mengintegrasikan Nilai Pada Rencana Pembelajaran Harian (Rpph) Anak Usia Dini Di Kabupaten Pidie Jaya. 3(1), 23-32.

Kemdikbud. (2014). Peraturan Menteri Pendidikan Dan Kebudayaan Republik Indonesia Nomor 10 Tahun 2014 Tentang Pelestarian Tradisi. 3 Februari 2014.Jakarta. 1-8.

Peraturan Menteri Pendidikan Dan Kebudayaan Republik Indonesia Nomor 146 Tahun 2014 Tentang Kurikulum 2013 Pendidikan Anak Usia Dini, (2014).

Lestariningrum, A., \& Handani, M. C. (2017). Analisis Pengembangan Kecerdasan Logis Matematis Anak Usia 5-6 Tahun Menggunakan Permainan Tradisional. Jpud - Jurnal Pendidikan Usia Dini, 11(2), 215-225. https://doi.org/10.21009/jpud.112.02

Lestariningrum, A., \& Wijaya, I. P. (2019). Pengembangan Model Pembelajaran Berbasis Budaya Lokal Di Tk Negeri Pembina Kota Kediri. Paudia: Jurnal Penelitian Dalam Bidang Pendidikan Anak Usia Dini, 8(2). https://doi.org/10.26877/paudia.v8i2.4755

Lubis, R., \& Khadijah, K. (2018). Permainan Tradisional Sebagai Pengembangan Kecerdasan Emosi Anak. Al-Athfal: Jurnal Pendidikan Anak, 4(2), 177-186. https://doi.org/10.14421/alathfal.2018.42-05

Musi, M. A., Sadaruddin, S., \& Mulyadi, M. (2018). Implementasi Permainan Edukatif Berbasis Budaya Lokal Untuk Mengenal Konsep Bilangan Pada Anak. Yaa Bunayya: Jurnal Pendidikan Anak Usia Dini, 1(2), 117-128.

Muzakki, M., \& Fauziah, P. Y. (2015). Implementasi Pembelajaran Anak Usia Dini Berbasis Budaya Lokal Di Paud Full Day School. Jppm (Jurnal Pendidikan Dan Pemberdayaan Masyarakat), 2(1), 39-54. https:// doi.org/10.21831/jppm.v2i1.4842

Nadlir, M. (2013). Perencanaan Pembelajaran Berbasis Karakter. Jurnal Pendidikan Agama Islam $\begin{array}{lllll}\text { (Journal Of Islamic } & \text { Education } & \text { 338-352. }\end{array}$ https://doi.org/10.15642/jpai.2013.1.2.338-352

Pamungkas, J., Hayati, N., \& Maryatun, I. B. (2016). Pengembangan Perencanaan Pembelajaran Paud Berbasis Budaya. Jurnal Pendidikan Anak, 5(2). https://doi.org/10.21831/jpa.v5i2.12389

Pribadi, B. A. (2009). Model Desain Sistem Pembelajaran. Jakarta: Dian Rakyat, 35.

Rahmawati, Y. (2015). Pengenalan Budaya Melalui Bercerita Untuk Anak Usia Dini. Jurnal Pendidikan Anak, 1(1). https://doi.org/10.21831/jpa.v1i1.2908

Suardana, I. N., \& Retug, N. (2017). Pelatihan Pembuatan Perangkat Pembelajaran Berbasis Budaya Bali Bagi Guru-Guru Sains Smp Di Kecamatan Buleleng. Widya Laksana, 2(1), 9-19. https://doi.org/10.23887/jwl.v2i1.9125

Suastra, I. W. (2010). Model Pembelajaran Sains Berbasis Budaya Lokal Untuk Mengembangkan Potensi Dasar Sains Dan Nilai Kearifan Lokal Di Smp. Jurnal Pendidikan Dan Pengajaran, 43(1).

Sudaryono. (2016). Metode Penelitian Pendidikan. Kencana.

Sugiyono. (2016). Metode Penelitian Kuantitatif, Kualitatif Dan R\&D. Alfabeta.

Widiastuti, S. (2012). Pembelajaran Proyek Berbasis Budaya Lokal Untuk Menstimulasi Kecerdasan Majemuk Anak Usia Dini. Jurnal Pendidikan Anak, 1(1). https://doi.org/10.21831/jpa.v1i1.2907

Wuryandani, W. (2010). Integrasi Nilai-Nilai Kearifan Lokal Dalam Pembelajaran Untuk Menanamkan Nasionalisme Di Sekolah Dasar. Prosiding Seminar Nasional Lembaga Penelitian Uny, 1-10.

Yani, S. J. L. A., \& Timur, S. J. (2017). Pelibatan Orang Tua Bernuansa Kearifan Lokal Dalam Pembelajaran Anak Usia Dini. Jurnal Pendidikan Anak Usia Dini, 11(1), 130-145. https://doi.org/10.21009/doi.111.09

Yetti, E., \& Juniasih, I. (2016). Implementasi Model Pembelajaran Tari Pendidikan Untuk Meningkatkan Kecerdasan Kinestetik Anak Usia Dini Melalui Metode Pembelajaran Aktif ( Pengembangan Model Di Taman Kanak-Kanak Labschool Jakarta Pada Kelompok B). Jpud - Jurnal Pendidikan Usia Dini, 10(2), 385-400. https://doi.org/10.21009/jpud.102.11 